\title{
COMPARISION OF MYCOTOXINS CONTENT FOUR IMPORTED WHEAT TO EGYPT
}

\author{
Ayman H. El-Naggar ${ }^{* *}$, M.A. Abed El-Samie ${ }^{2}$ and S.I. Ghoneim ${ }^{2}$
}

1. Agric. Quarantine, Minist. Agric., Egypt.

2. Food and Diary Sci. and Technol. Dept., Fac. Environ. Agric. Sci., Arish Univ., Egypt.

\begin{abstract}
Wheat is comprised the most important grain and single largest crop by area in Egypt. Despite this fact, Egypt is heavily dependent on imports wheat to meet its consumption needs. The objective of the present study was to determine some mycotoxins (aflatoxin B1, total B1, B2, G1, and G2, ochratoxin A (OTA), deoxynivalenol (DON) and zearalenone (ZON)) in wheat grains imported from four countries (France, Romania, Russia and Ukraine). The tested five samples were obtained from batches imported ate five different times of the year. The results showed that Ukrainian wheat was the beast which contained the least mycotoxins values. Total B1, B2, G1 and G2 of Ukrainian wheat ranged from 0.767 to $1.60 \mu \mathrm{g} . \mathrm{kg}^{-1}$, while OTA, DON and ZON were ranged from 0.50 to $1.367,48.90$ to 222.33 and 40.47 to 67.17 $\mu \mathrm{g} . \mathrm{kg}^{-1}$, respectively.
\end{abstract}

Key words: Wheat grain, Aflatoxin, deoxynivalenol, Ochratoxin, zearalenone.

\section{INTRODUCTION}

Wheat is considered of to be the greatest importance among cereals because of its processing characteristics; it is basically classified into hard, soft, and durum categories. Wheat quality cannot be simply defined since it changes depending on the workers (from the farmer to those in the processing industry) and end-use (from flour to bread, pasta, or cookies) (Marie and Ivan, 2009). Wheat is one of the most important sources of nutrition in Egypt. Resulting from its economic and social dimensions and feeding habits, the Egyptian population depends mainly on baladi bread as a source of food meals being considered relatively cheap compared to other alternative sources such as rice and potatoes (Dawoud, 2017). Wheat is the dominant crop in many countries including Egypt, as it is used for human food and livestock feed. Quality of wheat depends not only on its adaptability and high yield potential but also on the gluten protein fraction which confers the viscoelastic properties that allow dough to be processed into bread, pasta, noodles, and other food products. Wheat also contains essential amino acids, minerals, vitamins, beneficial phytochemicals and dietary fiber components which are important to the human diet (Shewry, 2009).

The domestic wheat production is estimated by about eight million ton produced from three million feddan. While the annual wheat consumption is fluctuated between 12 to 14 million tons .In other words, the gap between production and consumption lies between four to six million tons annually (Anas, 2015; Gaber and Mamdouh, 2015; FAO, 2017).

Mycotoxins are natural food and feed contaminants, mainly produced by moulds of genera Aspergillus, Penicillium and Fusarium. The number of mycotoxins known to exert toxic effect on human and

\footnotetext{
* Correspondence Author: + 201004214948

Email: aimanngar@yahoo.com
} 
animal health is constantly increasing, as well as the legislative provisions made to control their presence in food and feed (Zinedine et al., 2006). Currently, more than 400 mycotoxins are identified in the world. Considering their heat stability, these substances constitute a potential risk for human and animal health. The chemical and biological properties of mycotoxins and their toxic effects are extremely variable. These effects are carcinogencity, genotoxicity, teratogenicity, nephrotoxicity, hepatotoxicity and immunotoxicity. Mycotoxins are not only dangerous for the health of consumers, but they also deteriorate the market able quality of the contaminated products, causing heavy economic losses (Zinedine and Manes, 2009). Aflatoxins (AFs) B1, B2, G1 and G2 are produced by various strains of Aspergillus, mainly by A. flavus, $A$. parasiticus, $A$. nomius and $A$. tamarii. They have immunotoxic, mutagenic and carcinogenic effects (Moss, 1998). Aflatoxins are often present in cereals (maize, sorghum, rice, and wheat), oilseeds, spices and nuts. Aflatoxins were classified as group 1 carcinogen by the International Agency for Research on Cancer (IARC). Aflatoxin B1 is the most frequent and the most toxic one (IARC, 1993). Ochratoxin A is a secondary fungi metabolite mainly produced by Penicillium verrucosum, Aspergillus ochraceus and Aspergillus carbonarius (Eskola et al., 2001). These fungi are natural opportunist biodeterioration agents of carbohydrate-rich agricultural commodities. Therefore, this mycotoxin can occur in a large variety of commodities, such as cereals, dried fruits, coffee, beer, wine, and because of carry-over effect, in milk, blood, liver, kidney, and poultry meat from animals fed with contaminated feed (Mantle, 2002). Zearalenone is an estrogenic mycotoxin produced by several species of the fungal genera Fusarium graminearum and Fusarium culmorum. It widely exists in maize, barley, wheat, oats, sorghum and sesame seeds, as well as in hay and corn silage, which are prime ingredients in many food products for humans and animals (CAST, 2003). ZON is classified by IARC under group 3 carcinogen (IARC, 1999). Deoxynivalenol (DON) is a member of the trichothecene family of mycotoxins. The occurrence of deoxynivalenol is associated primarily with Fusarium graminearum and Fusarium culmorum, both of which are important plantpathogens commonly found in cereals and other crops (JECFA, 2001). DON is commonly detected in cereals and grains, particularly in wheat, barley, maize and their byproducts. Although DON is among the least toxic of the trichothecenes, it is the most frequently detected one throughout the world, and its occurrence is considered to be an indicator of the possible presence of other, more toxic trichothecenes (Lombaert, 2002).

A wide gap in self-sufficiency between the production and consumption of food occurred in the light of the increasing population, rising standards of living, declining of trade in food grains and high prices in the market (Gerber, 2014).Cereals and other crops are very susceptible to fungal attacks during its growth in the field and also storage. Depending on environmental conditions and other factors, a fungal attack may result in mycotoxin contamination of the crop. These toxins are stable compounds and do not completely degrade at high temperatures (Kabak, 2009); therefore, mycotoxins can contaminate processed foods and enter the human food chain through cereal-derived foods. The main mycotoxins, due to their toxicity and prevalence, are aflatoxins (AFs) and ochratoxin A (OTA) and to a lesser extent, zearalenone (ZON), among others.

\section{MATERIALS AND METHODS}

\section{Raw Materials}

Four types of imported wheat were used in their assessment, namely French wheat, 
Romanian wheat, Russian wheat and Ukrainian wheat. Samples were drawn from imported wheat shipments when they reached the ports of (Alexandria, El Dekhela and Damietta), the biggest ports in Egypt receiving imported wheat. The samples drawn in five importing intervals including $1^{\text {st }}$ interval (July-August/2014), $2^{\text {nd }}$ interval (September- October / 2014), $3^{\text {rd }}$ interval (November-December / 2014), $4^{\text {th }}$ interval (January-February/ 2015) and the $5^{\text {th }}$ interval (March-April/2015). Thus, the aim of this study is to detect some mycotoxins (aflatoxin B1, total B1, B2, G1, and G2, ochratoxin A (OTA), deoxynivalenol $(\mathrm{DON})$ and zearalenone $(\mathrm{ZON})$ ), in wheat grain imported from four countries (France, Romania, Russia and Ukraine).

\section{Mycotoxin Determination}

\section{Reagents preparation}

Phosphate buffered saline (PBS) was prepared by dissolving potassium chloride $(0.2 \mathrm{~g})$, potassium phosphate dibasic $(0.2$ $\mathrm{g})$, sodium phosphate dibasic (1.16 g) and sodium chloride $(8 \mathrm{~g})$ in $900 \mathrm{ml}$ water. The $\mathrm{pH}$ of the solution was adjusted to 7.40 with $\mathrm{HCl}$ or $\mathrm{NaOH}$, and two drops of Tween 20 were added. Finally, the volume was adjusted to one liter

\section{Standard solutions}

A stock standard solution containing 500 $\mu \mathrm{g} / 1$ of AFB1, AFG1 and OTA, $125 \mu \mathrm{g} / 1$ of AFB2 and AFG2 and $20 \mathrm{mg} / \mathrm{L}$ of $\mathrm{ZON}$ and DON were prepared by diluting different standard solution volumes of each mycotoxin in a mixture of acetonitrile and methanol $(50: 50 ; V / V)$. Working standard solutions of AFB1, AFG1 and OTA (100, 10 and $1 \mu \mathrm{g} / \mathrm{l}), \mathrm{AFB} 2$ and $\mathrm{AFG} 2(25,2.5$ and $0.25 \mu \mathrm{g} / \mathrm{l}), \mathrm{ZON}$ and DON (4000, 400 and $40 \mu \mathrm{g} / 1)$ respectively, were prepared by dilution from this stock standard solution. All prepared solutions were stored at $-20^{\circ} \mathrm{C}$ and maintained at room temperature and in darkness for $30 \mathrm{~min}$ before their use. Calibration samples were prepared by evaporating a given volume of the working standard solution under vacuum at $40^{\circ} \mathrm{C}$ in rotary evaporator (Gene $\mathrm{Vac}$ ). The residue was then dissolved in $150 \mu \mathrm{l}$ of a mixture (40:60) of acetonitrile - methanol (50:50) and water, both acidified with $0.5 \%$ formic acid. The acetonitrile extract of wheat samples were evaporated and dissolved in the same way.

\section{Sample preparation, mycotoxins extraction}

The method used for mycotoxin extraction from wheat samples is based on that which was described by Göbel and Lusky (2004), with some modifications. Three hundred grams of wheat were ground and screened, using a sieve size of 0.75 $\mathrm{mm} .10 \mathrm{~g}$ of milled sample were extracted with $50 \mathrm{ml}$ of a mixture of acetonitrilewater $(60: 40, V / V)$ in an orbital shaker for $30 \mathrm{~min}$. The extract was filtered and then 10 $\mathrm{ml}$ of the filtrate were mixed with $40 \mathrm{ml}$ of PBS. The mixture was centrifuged (6249 $\mathrm{xg}$ ) at $4^{\circ} \mathrm{C}$ for $15 \mathrm{~min}$. Fifteen milliliters of the supernatant were transferred to an $\mathrm{AOZ}$ immunoaffinity column (Vicam), the flow rate was adjusted to $0.9 \mathrm{ml}$ per min preconditioned with $3 \mathrm{ml}$ of water and $10 \mathrm{ml}$ of PBS. After the sample had passed, the column was washed with $5 \mathrm{ml}$ of PBS and $15 \mathrm{ml}$ of water. Finally, the column was dried with air and the mycotoxins were eluted with $3 \mathrm{ml}$ of acetonitrile, after maintaining in contact with acetonitrile and column antibodies for $5 \mathrm{~min}$. The extract was evaporated to dryness in rotary evaporator and the residue was re-extracted as previously indicated. The sample was maintained at $4^{\circ} \mathrm{C}$ in the chromatograph tray until its analysis and mycotoxins were determination by HPLC with fluorescence detection (FLD) (María et al., 2011).

\section{Recovery of mycotoxins}

The value of recovery percentage was determined by comparing the peak areas of wheat blank samples spiked with different levels of mycotoxin compounds with the 
peak areas of the same standards prepared in methanol (the first preparation standard) then take sequence dilutions 50:50 methanol and acetic acid. The mean detector response of different mycotoxin samples postextracted with those prepared by adding the compound to extracted mycotoxin free wheat extract at the corresponding concentrations. All samples were established from an average of three replicate measurements.

\section{Calibration curve and quantification}

Calibration curve for each mycotoxin compound was prepared by spiking blank wheat extract at $0.1,0.2,1,5,10,20$ and $100 \mu \mathrm{g}^{-1}$. Similarly, control solutions (0.5, 50, and $100 \mu \mathrm{g}^{-1}$ ) were prepared. The calibration standards were obtained by serial dilution of working solutions with methanol, to yield final concentrations of $4.0,5.0,6.0,8.0,10$ and $20 \mu \mathrm{g}^{-1}$ for each mycotoxin compound for analysis of wheat sample and the quality control solutions were 5, 10, and $20 \mu \mathrm{g} 1^{-1}$. The internal standard solution was prepared by dilution of the stock solution with methanol to a final concentration of $20 \mu \mathrm{g} \mathrm{l}^{-1}$. The external standard method was applied for quantitative analysis. Standard curves were obtained by un weighted linear regression of the peak-area of the mycotoxin compound versus its known concentration. The linear regression equation of the standard curve was used to calculate the concentration of both of the control and unknown samples by peak area matching to concentration axis.

\section{Statistical Analysis}

Data analyzed by using completely randomized design (analysis of variance) and producer using MSTAT-C package differences pattern (Michigan University, 1983). Means were compared by using each of least significant differences (LSD) (Steel and Torrie, 1980) and Dunkan's multiple range test (Duncan, 1955) at the 5\% level.

\section{RESULTS AND DISCUSSION}

\section{Aflatoxin B1 (AFB1) Content}

Aflatoxin B1 (AFB1) contents ( $\mu \mathrm{g} \cdot \mathrm{kg}^{-1}$ ) in wheat samples were recorded as $\mu \mathrm{g} . \mathrm{kg}^{-}$ ${ }^{1}$ and were presented in Table 1 .

From the results it could be noted that, AFB1 contents of French wheat all over the importing studied intervals was the least among all other wheat originated from Ukraine, Romania and Russia, as the French wheat samples' values of AFB1 ranged from 0.167 to $0.400 \mu \mathrm{g} . \mathrm{kg}^{-1}$ with an average of $0.288 \mu \mathrm{g} . \mathrm{kg}^{-1}$. These results are in accordance with the results of Odoemelam and Osu (2008) who found that AFB1 in wheat was in the range of 0.17 to $0.2 \mu \mathrm{g} \cdot \mathrm{kg}^{-1}$.

Higher ranges of AFB1 $(0.420,0.572$ and $0.300 \mu \mathrm{g} . \mathrm{kg}^{-1}$ ) were found in Russian, Romanian and Ukrainian wheat samples respectively. Within the French wheat samples, $1^{\text {st }}$ interval got the minimum value of (AFB1) $0.167 \mu \mathrm{g} . \mathrm{kg}^{-1}$, while $3^{\text {rd }}$ interval had the maximum value of AFB1 $(0.400$ $\left.\mu \mathrm{g} . \mathrm{kg}^{-1}\right)$, respectively.

The values of AFB1 of the imported Ukrainian wheat were in the range of 0.133 to $0.467 \mu \mathrm{g} . \mathrm{kg}^{-1}$ with an average of 0.300 $\mu \mathrm{g} . \mathrm{kg}^{-1}$. Within this wheat origin (Ukraine) fifth interval scored the minimum value of AFB1 $\left(0.133 \mu \mathrm{g} \cdot \mathrm{kg}^{-1}\right)$, followed by second interval $\left(0.233 \mu \mathrm{g} \cdot \mathrm{kg}^{-1}\right)$. The maximum value of (AFB1) was found in the $3^{\text {rd }}$ interval with score $0.467 \mu \mathrm{g} \cdot \mathrm{kg}^{-1}$.

The values of AFB1 of the imported Russian wheat samples were in the range of 0.367 to $0.500 \mu \mathrm{g} . \mathrm{kg}^{-1}$ with an average of $0.420 \mu \mathrm{g} . \mathrm{kg}^{-1}$, and the minimum AFB1 values were that of first and fourth intervals with similar score $0.367 \mu \mathrm{g} . \mathrm{kg}^{-1}$. A maximum value of AFB1 was that of the $2^{\text {nd }}$ interval with score $0.500 \mu \mathrm{g} \cdot \mathrm{kg}^{-1}$. 
SINAI Journal of Applied Sciences (ISSN: 2314-6079) Vol. (7) Is. (1), Apr. 2018

Table (1): Aflatoxin (B1) content of four imported wheat in five intervals from Jul. 2014 to Apr. $2015\left(\mu \mathrm{g} \cdot \mathrm{kg}^{-1}\right)$

\begin{tabular}{|c|c|c|c|c|c|c|}
\hline \multirow[t]{2}{*}{ Origin } & \multicolumn{5}{|c|}{ Intervals } & \multirow{2}{*}{$\begin{array}{c}\text { Interval mea } \\
\pm \mathrm{SD}\end{array}$} \\
\hline & Jul. / Aug. & Sep. / Oct. & Nov. / Dec. & Jan. / Feb. & Mar. / Apr. & \\
\hline French Wheat & $0.167^{\mathrm{fg}} \pm 0.12^{1}$ & $0.240^{\mathrm{e}-\mathrm{g}} \pm 0.05$ & $0.400^{c-e} \pm 0.10$ & $0.333^{\mathrm{c-f}} \pm 0.06$ & $0.300^{d-g} \pm 0.10$ & $0.288^{\mathrm{c}} \pm 0.11$ \\
\hline Romanian wheat & $0.400^{c-e} \pm 0.10$ & $0.593^{\mathrm{ab}} \pm 0.06$ & $0.400^{c-e} \pm 0.10$ & $0.766^{\mathrm{a}} \pm 0.12$ & $0.700^{\mathrm{a}} \pm 0.10$ & $0.572^{\mathrm{a}} \pm 0.18$ \\
\hline Russian wheat & $0.367^{c-e} \pm 0.12$ & $0.500^{\mathrm{bc}} \pm 0.10$ & $0.467^{b-d} \pm 0.12$ & $0.367^{\mathrm{ce}} \pm 0.06$ & $0.400^{c-e} \pm 0.17$ & $0.420^{\mathrm{b}} \pm 0.11$ \\
\hline Ukrainian wheat & $0.300^{\mathrm{d}-\mathrm{g}} \pm 0.10$ & $0.233^{\mathrm{f}-\mathrm{g}} \pm 0.12$ & $0.467^{b-d} \pm 0.12$ & $0.367^{\mathrm{ce}} \pm 0.06$ & $0.133^{\mathrm{g}} \pm 0.06$ & $0.300^{\mathrm{c}} \pm 0.14$ \\
\hline Interval mean \pm SD & $0.309^{\mathrm{b}} \pm 0.13$ & $0.392^{\mathrm{ab}} \pm 0.17$ & $0.434^{\mathrm{a}} \pm 0.10$ & $0.458^{\mathrm{a}} \pm 0.20$ & $0.383^{\mathrm{ab}} \pm 0.24$ & $0.395 \pm 0.18$ \\
\hline \multicolumn{7}{|l|}{ LSD 0.05} \\
\hline Among [Origin (O.)] & \multicolumn{3}{|c|}{ Among [interval (I.)] } & & \multicolumn{2}{|c|}{ Interaction (O. X I.) } \\
\hline $0.0116^{* *}$ & \multicolumn{3}{|c|}{$0.0113^{*}$} & \multicolumn{3}{|c|}{$0.0118^{* *}$} \\
\hline
\end{tabular}

- Data are expressed as means (3 replicates) $\pm \mathrm{SD}$

- Averages of origin in the same column having the same superscripts are not significantly different, same averages in interval raw which having same superscripts are not significantly different at $\mathrm{P} \leq 0.05$.

The highest AFB1value were obtained by the Romanian wheat samples with a range of 0.400 to $0.766 \mu \mathrm{g} \cdot \mathrm{kg}^{-1}$ and an Average of $0.572 \mu \mathrm{g} \cdot \mathrm{kg}^{-1}$, and minimum AFB1 values were that of first and third intervals with similar score $0.400 \mu \mathrm{g} \cdot \mathrm{kg}^{-1}$. The maximum value of AFB1 was that of the $2^{\text {nd }}$ interval with score $0.593 \mu \mathrm{g} \cdot \mathrm{kg}^{-1}$.

Among intervals, first interval was the least in AFB1 as it contained an average of $0.309 \mu \mathrm{g} \cdot \mathrm{kg}^{-1}$, followed by fifth and second intervals with averages of 0.383 and 0.392 $\mu \mathrm{g} . \mathrm{kg}^{-1}$. That may be related to the high temperature in the first interval which didn't allow the growth of molds.

EOS (2015) stated that AFB1content should not exceed $2 \mu \mathrm{g} \cdot \mathrm{kg}^{-1}$, and the obtained results indicated that all wheats from Ukraine, Russia, Romania and France are acceptable. Ukrainian wheat contained the least AFB1contents are compared with those imported from Romania and Russia. Also the first and fifth intervals achieved the lowest level of AFB1 content.

All results Analyses of aflatoxins in wheat were performed and all the analyzed samples were lower than limit of detection and also agree with Zinedine $\boldsymbol{e t}$ al. (2006).

\section{Total Aflatoxin (B1, B2, G1, and G2) Contents}

Total Aflatoxin (B1, B2, G1, and G2) contents expressed as $\left(\mu \mathrm{g} . \mathrm{kg}^{-1}\right)$ of wheat samples imported from France, Romania, Russia and Ukraine were all recorded as $\mu \mathrm{g} . \mathrm{kg}^{-1}$ and were presented in Table 2 .

Ukrainian wheat samples contained the least amounts of total AF (B1, B2, G1 and G2) with the range of 0.767 to $1.600 \mu \mathrm{g} \cdot \mathrm{kg}^{-1}$. The average of the five intervals of Ukrainian wheat samples was $1.160 \mu \mathrm{g} . \mathrm{kg}^{-1}$ which showed to be the lowest comparing to $1.547,1.743$ and $2.147 \mu \mathrm{g} . \mathrm{kg}^{-1}$ for Russian, French, and Romanian wheat samples, respectively. Within the Ukrainian wheat samples, $5^{\text {th }}$ interval (Mar/Apr) got the lowest total contents of AF (B1, B2, G1, and $\mathrm{G} 2$ ), recorded $0.767 \mu \mathrm{g} \cdot \mathrm{kg}^{-1}$, while the third interval showed the highest value $\left(1.600 \mu \mathrm{g} \cdot \mathrm{kg}^{-1}\right)$ of total AF (B1, B2, G1, and G2).

Russian wheat showed higher values of total AF (B1, B2, G1, and G2) being $\left(0.800-2.233 \mu \mathrm{g} . \mathrm{kg}^{-1}\right)$ with an average of $1.547 \mu \mathrm{g} . \mathrm{kg}^{-1}$, the first interval of Russian wheat sample had the lowest total AF contents of all samples $\left(0.800 \mu \mathrm{g} . \mathrm{kg}^{-1}\right)$ while 
Table (2): Total AF (B1-B2-G1-G2) of four imported wheat from France, Romania, Russia and Ukraine

\begin{tabular}{|c|c|c|c|c|c|c|}
\hline \multirow[t]{2}{*}{$\overline{\text { Origin }}$} & \multicolumn{5}{|c|}{ Total AF (B1,B2,G1 and G2) $\left(\mu \mathrm{g} . \mathrm{kg}^{-1}\right)$} & \multirow{2}{*}{$\begin{array}{l}\text { Interval mean } \\
\quad \pm \text { SD }\end{array}$} \\
\hline & Jul. Aug & Sep. Oct & Nov. Dec & Jan. Feb & Mar. Apr & \\
\hline$\overline{\text { French Wheat }}$ & $0.450^{k} \pm 0.03^{1}$ & $3.233^{\mathrm{a}} \pm 0.25$ & $1.767^{\mathrm{de}} \pm 0.15$ & $1.733^{\mathrm{de}} \pm 0.15$ & $1.533^{\mathrm{e}-\mathrm{g}} \pm 0.21$ & $1.743^{\mathrm{b}} \pm 0.93$ \\
\hline Romanian wheat & $2.733^{\mathrm{b}} \pm 0.15$ & $2.200^{c} \pm 0.36$ & $0.900^{\mathrm{ij}} \pm 0.10$ & $3.167^{\mathrm{a}} \pm 0.35$ & $1.733^{\mathrm{de}} \pm 0.15$ & $2.147^{\mathrm{a}} \pm 0.84$ \\
\hline Russian wheat & $0.800^{\mathrm{jk}} \pm 0.10$ & $2.000^{\mathrm{cd}} \pm 0.26$ & $1.467^{\mathrm{e}-\mathrm{g}} \pm 0.15$ & $1.233^{g-i} \pm 0.25$ & $2.233^{\mathrm{c}} \pm 0.21$ & $1.547^{\mathrm{b}} \pm 0.56$ \\
\hline Ukrainian wheat & $0.933^{\mathrm{h}-\mathrm{j}} \pm 0.15$ & $1.233^{g-i} \pm 0.06$ & $1.600^{\mathrm{ef}} \pm 0.26$ & $1.267^{\mathrm{fh}} \pm 0.25$ & $0.767^{\mathrm{jk}} \pm 0.15$ & $1.160^{\mathrm{c}} \pm 0.34$ \\
\hline Interval mean $\pm \mathrm{SD}$ & $1.229^{\mathrm{d}} \pm 0.93$ & $2.167^{\mathrm{a}} \pm 0.78$ & $1.434^{\mathrm{cd}} \pm 0.37$ & $1.850^{\mathrm{b}} \pm 0.85$ & $1.567^{\mathrm{c}} \pm 0.57$ & $1.649 \pm 0.78$ \\
\hline \multicolumn{7}{|l|}{ LSD 0.05} \\
\hline $\begin{array}{c}\text { Among [Origin }(\mathrm{O} .)] \\
0.23^{* *}\end{array}$ & \multicolumn{3}{|c|}{$\begin{array}{c}\text { Among [interval (I.)] } \\
0.23^{* *}\end{array}$} & \multicolumn{2}{|c|}{ Interaction (O. X I.) } & \\
\hline
\end{tabular}

- Data are expressed as means (3 replicates) $\pm \mathrm{SD}$

- Averages of origin in the same column having the same superscripts are not significantly different, same averages in interval raw which having same superscripts are not significantly different at $\mathrm{P} \leq 0.05$.

the fifth interval had the highest contents in all tested samples $\left(2.233 \mu \mathrm{g} \cdot \mathrm{kg}^{-1}\right)$.

The total values of total AF content of the Romanian wheat samples were in the range of 0.900 to $3.167 \mu \mathrm{g} \cdot \mathrm{kg}^{-1}$ with an average of $2.147 \mu \mathrm{g} . \mathrm{kg}^{-1}$. Within this wheat samples. The third interval scored the lowest total value of AF content $(0.900$ $\left.\mu \mathrm{g} . \mathrm{kg}^{-1}\right)$. Were, the highest AF total value was that of the $4^{\text {th }}$ interval being 3.167 $\mu \mathrm{g} . \mathrm{kg}^{-1}$.

Interval with the lowest contents of total $\mathrm{AF}$ was that of the first interval followed by the third interval with no significant differences with fifth interval followed by fourth interval and maximal contents was that of the second interval (Sep/Oct).

EOS (2015) stated that total values of AFB1, AFB2, and AFG1should not exceed than $4 \mu \mathrm{g} \cdot \mathrm{kg}^{-1}$, and the obtained results showed that all wheats imported from Ukraine, Russia, Romania and France are acceptable.

\section{Ochratoxin A (OTA) Content}

Table 3 shows the Total ochratoxin A (OTA) content expressed as $\mu \mathrm{g} \cdot \mathrm{kg}^{-1}$ of wheat samples imported from four origin countries (France, Romania, Russia and Ukraine).

From the results, it could be reported that OTA content of the Ukrainian wheat was the least among all other wheat samples, as it had OTA content ranged from 0.5 to $1.367 \mu \mathrm{g} . \mathrm{kg}^{-1}$ with an average of $1.047 \mu \mathrm{g} \cdot \mathrm{kg}^{-1}$ which showed to be lower comparing to average values of 1.153, 1.207 and $1.467 \mu \mathrm{g} \cdot \mathrm{kg}^{-1}$ for Russian, French, and Romanian wheat samples, respectively. Within the Ukrainian wheat samples, the first interval got the minimum $0.5 \mu \mathrm{g} \cdot \mathrm{kg}^{-1}$ OTA value, while the fifth interval had the maximum $1.367 \mu \mathrm{g} . \mathrm{kg}^{-1}$ OTA among content.

French and Russian wheat came above Ukrainian ones regarding the OTA content with no significant differences $\mathrm{P} \leq 0.05$. French and Russian wheat contained the ranges of 1.067 to $1.367 \mu \mathrm{g} \cdot \mathrm{kg}^{-1}$ and 0.367 to $1.5 \mu \mathrm{g} \cdot \mathrm{kg}^{-1}$, respectively, with averages of 1.207 and $1.153 \mu \mathrm{g} . \mathrm{kg}^{-1}$, respectively., OTA contents were significantly lower than that of the Romanian wheat samples which contained an average of $1.467 \mu \mathrm{g} . \mathrm{kg}^{-1}$ of OTA with the range of 0.633 to 2.400 $\mu \mathrm{g} . \mathrm{kg}^{-1}$. Within the Romanian wheat, the 
SINAI Journal of Applied Sciences (ISSN: 2314-6079) Vol. (7) Is. (1), Apr. 2018

Table (3): Ochratoxin A (OTA) of four imported wheat in five intervals from Jul. 2014 to Apr. $2015\left(\mu \mathrm{g} \cdot \mathrm{kg}^{-1}\right)$

\begin{tabular}{|c|c|c|c|c|c|c|}
\hline \multirow[t]{2}{*}{ Origin } & \multicolumn{5}{|c|}{ Intervals } & \multirow{2}{*}{$\begin{array}{c}\text { Interval } \\
\text { mean } \pm \text { SD }\end{array}$} \\
\hline & Jul/Aug & Sep/Oct & Nov/Dec & Jan/Feb & Mar/Apr & \\
\hline French Wheat & $1.067^{\mathrm{ef}} \pm 0.12^{1}$ & $1.067^{\mathrm{ef}} \pm 0.12$ & $1.367^{\mathrm{ce}} \pm 0.12$ & $1.167^{\mathrm{ef}} \pm 0.29$ & $1.367^{\mathrm{ce}} \pm 0.06$ & $1.207^{\mathrm{b}} \pm 0.19$ \\
\hline Romanian wheat & $0.633^{\mathrm{gh}} \pm 0.15$ & $1.567^{\mathrm{c}} \pm 0.25$ & $0.700^{\mathrm{g}} \pm 0.10$ & $2.033^{\mathrm{b}} \pm 0.25$ & $2.400^{\mathrm{a}} \pm 0.10$ & $1.467^{\mathrm{a}} \pm 0.75$ \\
\hline Russian wheat & $1.333^{\mathrm{c}-\mathrm{f}} \pm 0.06$ & $1.267^{\mathrm{c}-\mathrm{f}} \pm 0.25$ & $1.500^{\mathrm{cd}} \pm 0.17$ & $0.367^{\mathrm{h}} \pm 0.12$ & $1.300^{\mathrm{c}-\mathrm{f}} \pm 0.20$ & $1.153^{\mathrm{b}} \pm 0.44$ \\
\hline Ukrainian wheat & $0.500^{\mathrm{gh}} \pm 0.10$ & $1.200^{\mathrm{d}-\mathrm{f}} \pm 0.20$ & $1.033^{\mathrm{f}} \pm 0.15$ & $1.133^{\mathrm{ef}} \pm 0.12$ & $1.367^{\mathrm{c}-\mathrm{e}} \pm 0.15$ & $1.047^{\mathrm{b}} \pm 0.33$ \\
\hline Interval mean $\pm \mathrm{SD}$ & $0.883^{c} \pm 0.36$ & $1.275^{\mathrm{b}} \pm 0.26$ & $1.150^{\mathrm{b}} \pm 0.35$ & $1.175^{\mathrm{b}} \pm 0.64$ & $1.609^{\mathrm{a}} \pm 0.49$ & $1.219 \pm 0.49$ \\
\hline \multicolumn{7}{|l|}{ LSD 0.05} \\
\hline $\begin{array}{l}\text { Among [Origin }(\mathrm{O} .) \text { ] } \\
0.20^{* *}\end{array}$ & \multicolumn{4}{|c|}{ Among [interval (I.)] } & \multicolumn{2}{|c|}{ Interaction (O. X I.) } \\
\hline
\end{tabular}

maximum OTA content was that of the $5^{\text {th }}$ interval being $2.4 \mu \mathrm{g} . \mathrm{kg}^{-1}$ which also was the maximal value among all imported wheat samples.

EOS (2015) stated that the importing Ukrainian wheat OTA should not exceed 5 $\mu \mathrm{g} . \mathrm{kg}^{-1}$ max, and the obtained results showed that all imported wheats from Jul. 2014 to Apr. 2015 are acceptable, but the first interval from Jul. Aug 2014 was the best interval as it contained the lowest OTA content.

\section{Deoxynivalenol (DON) Content}

Deoxynivalenol (DON) contents (measured as $\left.\mu \mathrm{g} . \mathrm{kg}^{-1}\right)$ of the imported wheat samples, from four origins (France, Romania, Russia and Ukraine) within five importing intervals are presented in Table 4.

The results in Table 4 show that, DON content of Ukrainian wheat samples was the least comparing to that of French, Romania and Russia, as the DON contents in Ukrainian wheat ranged from 48.90 to $222.33 \mu \mathrm{g} \cdot \mathrm{kg}^{-1}$ with an average of 93.88 $\mu \mathrm{g} . \mathrm{kg}^{-1}$ comparing to the average values of
105.700, 117.512 and $156.200 \mu \mathrm{g} . \mathrm{kg}^{-1}$ for Russian, French, and Romanian wheat samples, respectively. Within the Ukrainian wheat samples, the $5^{\text {th }}$ interval (Mar. April) contained the minimum DON content being $48.90 \mu \mathrm{g} . \mathrm{kg}^{-1}$, while the first interval (Jul. Aug.) contained the maximum DON content $\left(222.33 \mu \mathrm{g} . \mathrm{kg}^{-1}\right)$.

The average of DON contents for the different intervals of Russian wheat samples was higher than that of the Ukrainian wheat. DON contents are ranged between 57.67 and $200.43 \mu \mathrm{g} . \mathrm{kg}^{-1}$ with an average of $105.7 \mu \mathrm{g} \cdot \mathrm{kg}^{-1}$. Within the Russian wheat samples, $5^{\text {th }}$ interval got the minimum value of DON recorded $57.67 \mu \mathrm{g} . \mathrm{kg}^{-1}$ while the $2^{\text {nd }}$ interval gave the maximum DON contents $200.43 \mu \mathrm{g} \cdot \mathrm{kg}^{-1}$.

The content of DON of the French wheat ranged between of 70.33 to $249.33 \mu \mathrm{g} . \mathrm{kg}^{-1}$ with an average of $117.512 \mu \mathrm{g} . \mathrm{kg}^{-1}$. The French wheat at the first interval scored the minimum content of DON with value of $70.33 \mu \mathrm{g} \cdot \mathrm{kg}^{-1}$, while the maximum DON of French wheat was that of the $5^{\text {th }}$ interval (Mar. Apr; 2015) being $249.33 \mu \mathrm{g} . \mathrm{kg}^{-1}$. 
Table (4): Deoxynivalenol (DON) content of four imported wheat in five intervals from Jul. 2014 to Apr. $2015\left(\mu \mathrm{gg} \mathrm{kg}^{-1}\right)$

\begin{tabular}{|c|c|c|c|c|c|c|}
\hline \multirow[t]{2}{*}{ Origin } & \multicolumn{5}{|c|}{ Intervals } & \multirow{2}{*}{$\begin{array}{c}\text { Interval mean } \\
\pm \mathrm{SD}\end{array}$} \\
\hline & Jul. / Aug. & Sep. / Oct. & Nov. / Dec. & Jan. /Feb. & Mar. Apr. & \\
\hline French Wheat & $70.33^{i} \pm 1.53^{1}$ & $90.12^{g^{g}} \pm 0.12$ & $92.08^{g^{g}} \pm 5.21$ & $85.70^{\mathrm{gh}_{\mathrm{h}}} \pm 3.84$ & $249.33^{\mathrm{a}} \pm 6.03$ & $117.512^{\mathrm{b}} \pm 68.76$ \\
\hline Romanian wheat & $184.33^{\mathrm{d}} \pm 7.37$ & $123.67^{\mathrm{e}} \pm 8.14$ & $189.00^{\mathrm{d}} \pm 3.61$ & $222.67^{\mathrm{b}} \pm 6.43$ & $61.33^{\mathrm{j}} \pm 4.16$ & $156.200^{\mathrm{a}} \pm 59.41$ \\
\hline Russian wheat & $88.67^{\mathrm{g}} \pm 1.53$ & $200.43^{\mathrm{c}} \pm 2.38$ & $70.73^{\mathrm{i}} \pm 1.36$ & $111.00^{\mathrm{f}} \pm 10.67$ & $57.67_{ \pm 2.35}^{\dot{j}}$ & $105.700^{\mathrm{c}} \pm 52.59$ \\
\hline Ukrainian wheat & $222.33^{\mathrm{b}} \pm 3.51$ & $79.43^{\mathrm{h}} \pm 1.34$ & $60.57^{\mathrm{i}} \pm 5.65$ & $58.17^{\mathrm{j}} \pm 2.82$ & $48.90^{\mathrm{k}} \pm 1.71$ & $93.88^{\mathrm{d}} \pm 67.33$ \\
\hline Interval mean \pm SD & $141.415^{\mathrm{a}} \pm 66.62$ & $123.413^{\mathrm{b}} \pm 49.61$ & $103.095^{\mathrm{c}} \pm 53.27$ & $119.385^{\mathrm{b}} \pm 65.52$ & $104.308^{c} \pm 87.64$ & $118.323 \pm 65.18$ \\
\hline \multicolumn{7}{|l|}{ LSD 0.05} \\
\hline $\begin{array}{c}\text { Among [Origin }(\mathrm{O} .)] \\
0.20^{* *}\end{array}$ & & \multicolumn{3}{|c|}{$\begin{array}{l}\text { Among [interval (I.)] } \\
0.20^{* *}\end{array}$} & \multicolumn{2}{|c|}{$\begin{array}{c}\text { Interaction (O. X I.) } \\
0.31^{* *}\end{array}$} \\
\hline
\end{tabular}

- Data are expressed as means (3 replicates) $\pm \mathrm{SD}$.

- Averages of origin in the same column having the same superscripts are not significantly different, same averages in interval raw which having same superscripts are not significantly different at $\mathrm{P} \leq 0.05$.

The maximum DON content was that of the Romanian wheat, as it ranged between of 61.33 to $222.67 \mu \mathrm{g} . \mathrm{kg}^{-1}$ with an average of $156.2 \mu \mathrm{g} \cdot \mathrm{kg}^{-1}$. Wheat imported from Romania in the fifth interval scored the minimum DON content which was $61.33 \mu \mathrm{g} \cdot \mathrm{kg}^{-1}$, while the maximum was that of the $4^{\text {th }}$ interval (Jan. Feb; 2015) with score $222.67 \mu \mathrm{g} \cdot \mathrm{kg}^{-1}$.

Regarding of the variance of time and intervals on the DON contents, it is clear that the first interval scored the maximum average $141.415 \mu \mathrm{g} . \mathrm{kg}^{-1}$ followed by the second and the fourth intervals which scored 123.413 and $119.385 \mu \mathrm{g} \cdot \mathrm{kg}^{-1}$, respectively. The lowest interval in DON content was the third and fifth intervals with no significant differences between them with scores 103.095 and $104.308 \mu \mathrm{g} \cdot \mathrm{kg}^{-1}$, respectively.

EOS (2015) stated that the imported Ukrainian wheat DON content should not exceed $1250 \mu \mathrm{g} \cdot \mathrm{kg}^{-1}$ max, and the results indicated that all wheats imported in Jul. 2014 to Apr. 2015 were acceptable, Ukrainian wheat was the least among all other wheat originated from France, Romania and Russia in DON contents.

EFSA Assesses EU Limits for Deoxynivalenol in Cereals. EFSA has recently delivered an Opinion on the risks for public health related to a possible increase of the maximum level (ML) of deoxynivalenol (DON) for certain semiprocessed cereal products from $750 \mu \mathrm{g} . \mathrm{kg}^{-}$ ${ }^{1}$ to $1000 \mu \mathrm{g} \cdot \mathrm{kg}^{-1}$ (EFSA, 2014).

\section{Zearalenone (ZON) Content}

Zearalenone (ZON) contents $\left(\mu \mathrm{g} \cdot \mathrm{kg}^{-1}\right)$ of wheat samples imported from four origin countries including France, Romania, Russia and Ukraine, within five importing intervals are presented in Table 5.

As shown in Table 5 the average of Zearalenone content of the Ukrainian wheat was the least among other wheat samples, range of the ZON content was 40.47 - 67.17 $\mu \mathrm{g} . \mathrm{kg}^{-1}$ with an average of $51.574 \mu \mathrm{g} . \mathrm{kg}^{-1}$. Among wheat imported from Ukraine, the second interval had the minimum $\mathrm{ZON}$ content $\left(40.47 \mu \mathrm{g} \cdot \mathrm{kg}^{-1}\right)$ followed by both third and first intervals with no significant differences between them (49.40 and 50.00 $\mu \mathrm{g} . \mathrm{kg}^{-1}$, respectively). The fifth interval had the highest ZON content $\left(67.17 \mu \mathrm{g} \cdot \mathrm{kg}^{-1}\right)$. The average of $\mathrm{ZON}$ of the French wheat was $53.306 \mu \mathrm{g}^{\mathrm{kg}}{ }^{-1}$, which was not significantly different from that of the Ukrainian wheat samples These results are accepted in accordance with the result of 
SINAI Journal of Applied Sciences (ISSN: 2314-6079) Vol. (7) Is. (1), Apr. 2018

Table (5): Zearalenone (ZON) content of four imported wheat in five intervals from Jul. 2014 to Apr. $2015\left(\mu \mathrm{g} . \mathrm{kg}^{-1}\right)$

\begin{tabular}{|c|c|c|c|c|c|c|}
\hline \multirow[t]{2}{*}{$\overline{\text { Origin }}$} & \multicolumn{5}{|c|}{ Intervals } & \multirow{2}{*}{$\begin{array}{l}\text { Interval mean } \\
\quad \pm \mathrm{SD}\end{array}$} \\
\hline & Jul. /Aug. & Sep. /Oct. & Nov. / Dec. & Jan. / Feb. & Mar. / Apr. & \\
\hline French Wheat & $25.67^{\mathrm{m}} \pm 4.04^{1}$ & $70.15^{\mathrm{c}} \pm 0.17$ & $68.71^{\mathrm{c}} \pm 2.35$ & $48.33^{\mathrm{ij}} \pm 3.51$ & $53.67^{\mathrm{gh}} \pm 1.53$ & $\overline{53.306^{\mathrm{c}} \pm 16.91}$ \\
\hline Romanian wheat & $79.33^{\mathrm{b}} \pm 3.06$ & $59.00^{\mathrm{ef}} \pm 3.61$ & $63.33^{\mathrm{de}} \pm 4.16$ & $86.00^{\mathrm{a}} \pm 5.29$ & $45.33^{\mathrm{j} \mathrm{k}} \pm 2.52$ & $66.598^{\mathrm{a}} \pm 15.41$ \\
\hline Russian wheat & $60.67^{\mathrm{e}} \pm 1.15$ & $69.40^{c} \pm 0.56$ & $54.77^{\mathrm{fg}} \pm 0.68$ & $42.43^{\mathrm{kl}} \pm 2.14$ & $81.13^{\mathrm{b}} \pm 1.63$ & $61.680^{\mathrm{b}} \pm 13.60$ \\
\hline Ukrainian wheat & $50.00^{\mathrm{h}-\mathrm{j}} \pm 2.00$ & $40.47^{1} \pm 1.36$ & $49.40^{\mathrm{h}-\mathrm{j}} \pm 2.16$ & $50.83^{g-i} \pm 0.72$ & $67.17^{\mathrm{cd}} \pm 2.74$ & $51.574^{\mathrm{c}} \pm 9.10$ \\
\hline Interval mean $\pm \mathrm{SD}$ & $53.917^{\mathrm{c}} \pm 20.40$ & $59.755^{\mathrm{ab}} \pm 12.62$ & $59.053^{\mathrm{ab}} \pm 8.12$ & $56.898^{\mathrm{b}} \pm 18.06$ & $61.825^{\mathrm{a}} \pm 14.33$ & $58.290 \pm 15.03$ \\
\hline \multicolumn{7}{|l|}{ LSD 0.05} \\
\hline $\begin{array}{c}\text { Among [Origin }(\mathrm{O} .) \\
3.06^{* *} \\
\end{array}$ & & \multicolumn{3}{|c|}{$\begin{array}{l}\text { Among [interval (I.)] } \\
2.98^{* *}\end{array}$} & \multicolumn{2}{|c|}{$\begin{array}{c}\text { Interaction (O. X I.) } \\
4.68^{* *}\end{array}$} \\
\hline
\end{tabular}

(Zaied et al., 2012) who found that $\mathrm{ZON}$ in wheat was in the range of 36 to 61.31 $\mu \mathrm{g} . \mathrm{kg}^{-1}$.

The average of ZON content of the imported Russian wheat was higher than of French or Ukrainian wheat. The ZON content of Russian wheat was ranged from 42.43 to $81.13 \mu \mathrm{g} . \mathrm{kg}^{-1}$ with an average of $61.680 \mu \mathrm{g} \cdot \mathrm{kg}^{-1}$.

The content of ZON of the Romanian wheat was the highest, comparing to those of the other samples from France, Russia and Ukraine, which ranged between 45.33 to $86.00 \mu \mathrm{g} . \mathrm{kg}^{-1}$ with an average of 66.598 $\mu \mathrm{g} . \mathrm{kg}^{-1}$. The fifth interval had the minimum ZON content $\left(45.33 \mu \mathrm{g} \cdot \mathrm{kg}^{-1}\right)$ followed by both the second and the third intervals had (59.00 and $63.33 \mu \mathrm{g} . \mathrm{kg}^{-1}$, respectively). The maximum ZON content was that of the $4^{\text {th }}$ interval (Jan. Feb; 2015) recorded 86.00 $\mu \mathrm{g} . \mathrm{kg}^{-1}$.

Comparatively by taking interval as the factor, the first interval had the lowest ZON content $\left(53.917 \mu \mathrm{g} . \mathrm{kg}^{-1}\right)$ followed by the fourth, the third and the second intervals, while the fifth interval contained 61.825 $\mu \mathrm{g} . \mathrm{kg}^{-1}$ which was the highest average of ZON among all other intervals. The highest value of $\mathrm{ZON}$ was that of Russian wheat in the fifth interval recorded $81.13 \mu \mathrm{g} \cdot \mathrm{kg}^{-1}$.

EOS (2015) stated that ZON content should not exceed $100 \mu \mathrm{g} . \mathrm{kg}^{-1}$ max, and the obtained results assured that all imported wheats from Jul. 2014 to Aug. 2015 are acceptable, but the first interval from Jul. Aug; 2014 was the best one.

And all results exceeded the tolerable limit $(100 \mathrm{mg} / \mathrm{kg})$ as recommended by the European Union (European Commission, 2007).

\section{Conclusions}

The study focused on inspection and quality control of some wheat that Egypt import, recognizing how these freights correspond with the Egyptian standards. Some mycotoxins were determined and quantified in wheat grains imported from four countries at five intervals. The obtained results indicated that the Ukrainian wheat was the beast among all other wheat originated from France, Romania and Russia, followed by French wheat, Russian wheat and lastly Romanian wheat in most tests used (Total (B1-B2-G1-G2), Ochratoxin A (OTA) Deoxynivalenol (DON) and 
Zearalenone (ZON) and came in the second step in Aflatoxin (B1). Finally it is recommended to increase importing Ukrainian wheat.

\section{REFERENCES}

Anas, M.S.S. (2015). Breeding Bread Wheat for Resistance to Some Rusts. Ph. D. Thesis. Dep. Agronomy. Fac. Agric., Kafr El-Sheikh Univ., Egypt.

CAST (2003). Council for Agricultural Science and Technology. Occurrence of mycotoxins in food and feed. In: CAST, Editor, Mycotoxins: Risks in Plant, Animal and Human Systems. Task Force Report No. 139, Council for Agric. Sci. and Technol., Ames, IA, 36-47.

Dawoud, S.D.Z. (2017). Current status and future perspective of wheat production and consumption in Egypt. JAAS J., 5 (2): $35-45$.

Duncan, B.D. (1955). Multiple ranges and multiple F-tests. Biometric. 11, 1-42.

EOS (2015). Egyptian Organization for Standards. Standard Specification No. $1601 / 2005$ on basic requirements and descriptive criteria for wheat varieties. http://www.eos.org.eg

Eskola, M.; Parikka, P. and Rizzo, A. (2001). Trichothecenes, ochratoxin A and zearalenone contamination and Fusarium infection in Finnish cereal samples in 1998. Food Additives and Contaminants, 18(8): 707-718.

\section{European Commission (EC) 1126/2007 of} 28 September (2007). Setting maximum levels for certain contaminants in foodstuffs as regards Fusarium toxins in maize and maize products. Official $\mathrm{J}$. EU, 255: 14-17.

European Food Safety Authority (2014). Scientific Opinion on the risks for human and animal health related to the presence of modified forms of certain mycotoxins in food and feed. EFSA J., 12 (12): 3916.

FAO (2017). Food and Agriculture Organization Statistics, FAOSTAT. www.fao.org/faostat.

Gaber B.S. and Mamdouh, E.M. (2015). Some economic aspects of wheat in Egypt with emphasis on baladi bread manufacturing in Alexandria Governorate. Int. J. Soc. Sci. and Humanity, 5 (6): 501-508.

Gerber, A. (2014). Food Security as an Outcome of Food Systems. Available at: http://www.systemdynamics.org/confere nces/2014/proceed/papers/P1113.pdf.

Göbel, R. and Lusky, K. (2004). Simultaneous determination of aflatoxins, ochratoxin A, and zearalenone in grains by new immunoaffinity column. J. AOAC Int., 87(2): 411-416.

IARC (1993). International Agency for Research on Cancer Ochratoxin. A some naturally is occurring substances: Food items and constituents, heterocyclic aromatic amines and mycotoxins. Monographs on the evaluation of carcinogenic risk to humans, 56: 489-452.

IARC (1999). International Agency for Research on Cancer, Overall evaluations of carcinogenicity to humans. Monographs on the evaluation of carcinogenic risk to humans, IARC monographs (1): 1-36.

JECFA (2001). Joint FAO/WHO Expert Committee on Food Additives. Safety evaluation of certain mycotoxins in food (281-415). Rome, Italy: Food and Agric. Organization.

Kabak (2009). The fate of mycotoxins during thermal food processing Sci. Food 473 Agric., 89 549-554.

Lombaert, G.A. (2002). Methods for the determination of deoxynivalenol and 
other trichothecenes in foods. Mycotoxins and food safety, Kluwer Academic/Plenum Publishers, New York, 141-153.

Mantle, P.G. (2002). Risk assessment and the importance of ochratoxins. International Biodeterioration and Biodegradation, 50 (3-4): 143-146.

Marie H. and Ivan Š. (2009). Wheat Hardness in Relation to Other Quality Factors. Czech J. Food Sci., 27 (4): 240248.

María, I.; Laura, A.C.; Rebeca, R.; María, T.M.; Elena, G. and Elena, L. (2011). Validation of a UHPLC-FLD method for the simultaneous quantification of aflatoxins, ochratoxin A and zearalenone in barley. Food Chem., 127: 351-358

Michigan University (1983). Microcomputer statistical program, version 2. Michigan State University. East Linsing.

Moss, M.O. (1998). Recent studies of mycotoxins. J. Appl. Microbiol., 84: 6276.
Odoemelam, S.A. and Osu, C.I. (2008). Aflatoxin B1 Contamination of some edible grains marketed in Nigeria. J. Chem., 6 (2): 308-314

Shewry, P.R. (2009). Wheat. J. Exp. Bot., 60 (6): 1537-1553, 2009doi:10.1093/ jxb/erp058.

Steel, R.G.D. and Torrie, J.H. (1980). Principals and procedures of statistics: A biometrical approach $2^{\text {nd }}$ Ed. Mc. GrawHill Blook Co. New York.

Zaied, C.; Nidhal, Z.; Hassan, B. And Salwa, A. (2012). Natural occurrence of zearalenone in Tunisian wheat grains, Food Control, 25: 773-777

Zinedine, A.; Brera, C.B.; Elakhdari, S.; Catano, C.; Debegnach, F. and Angelini, S. (2006). Natural occurrence of mycotoxins in cereals and spices commercialized in Morocco. Food Control, 17: 868-874.

Zinedine, A. and Manes, J. (2009). Occurrence and legislation of mycotoxins in food and feed from Morocco. Food Control, 334-344. 


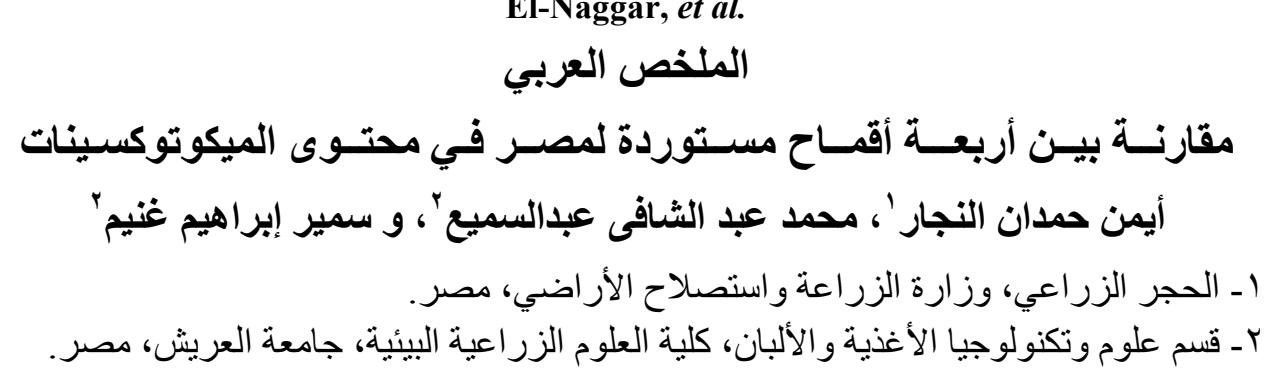

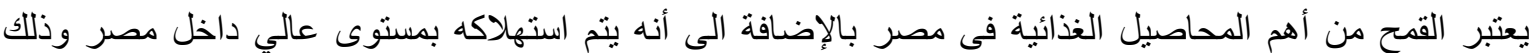

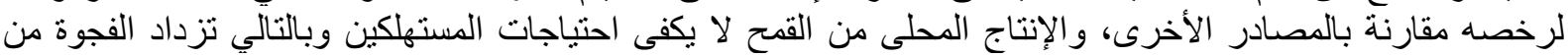

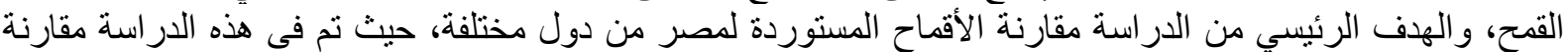

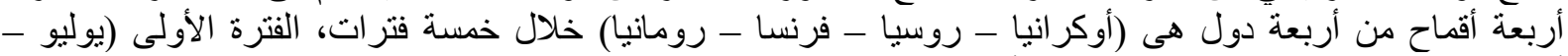

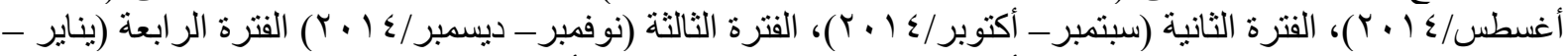

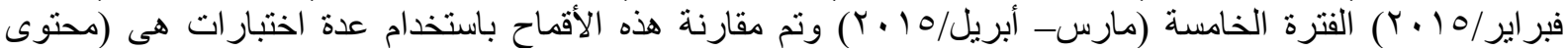

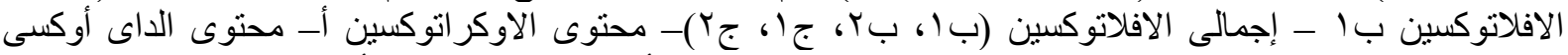

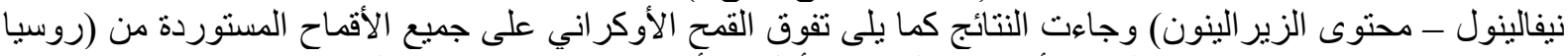

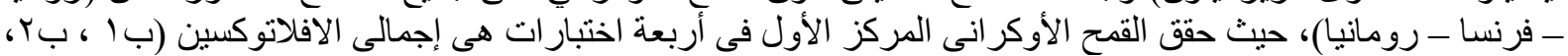

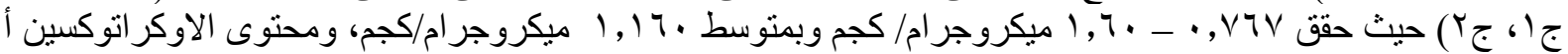

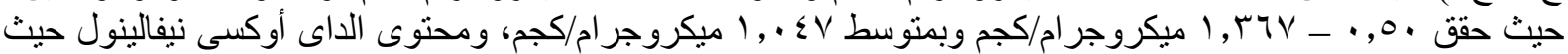

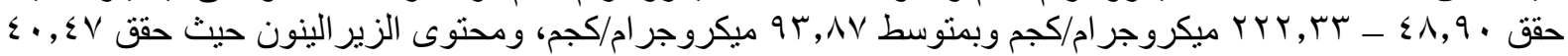

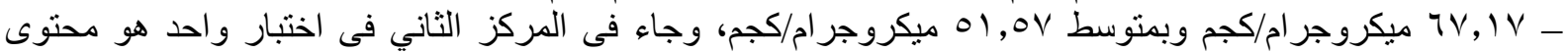

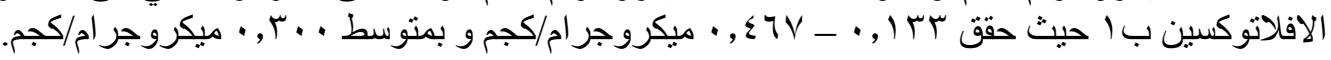
الكلمات الإسترشادية: حبة القمح، الافلاتوكسين، الداى أوكسى نيفالينول، الأوكر اتوكسين، الزير الينون.

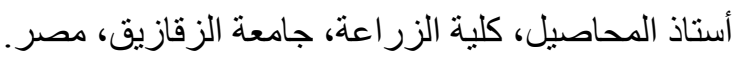

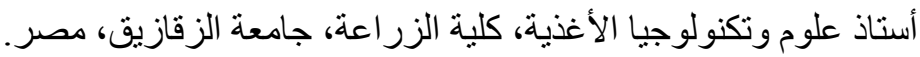

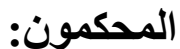

ا - أ.د. أحمد أحمد: عبدالغنى علي

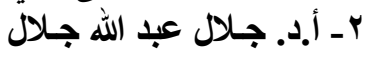

